\title{
Spørgetid
}

\section{Pres på Israel?}

Rune Lund (Enhedslisten) i spørgsmål nr. S 882 udenrigsminister Per Stig Møller:

"Vil udenrigsministeren på baggrund af de seneste israelske drab på civile foreslå $\mathrm{EU}$ at opsige handelspræferenceaftalen med Israel?”

\section{Rune Lund:}

Det drejer sig om, at vi jo i Israel og Palæstina har set, hvordan civile palæstinensere hele tiden dør på grund af israelsk ild, israelske kugler, israelske bomber. De 19 civile palæstinensere, som blev dræbt den 8 . november, er jo bare de sidste i en lang række af civile, som er døde. For siden den 25 juni i år, hvor den nu igangværende israelske offensiv startede i Gaza, er det faktisk sådan, at op imod 350 mennesker, civile palæstinensere, er døde, heraf 64 børn.

Det er faktisk endnu et eksempel på, at Israel ikke lever op til de forpligtelser, der er i den handelsaftale, der er mellem EU og Israel, som jo fordrer, at Israel skal respektere menneskerettighederne. Det kan man jo ikke sige at de gør. Så er det ikke snart på tide, at vi gør alvor ud af det, der står i den handelsaftale, og siger, at vi så må opsige handels- aftalen, når Israel ikke lever op til menneskerettighederne?

\section{Udenrigsministeren:}

Det, der er det gode ved handelsaftalen, er, at den giver os en platform til præcis at fremhæve, når vi synes, at Israel går over gevind.

Lad os holde fast i en ting: Israel har ret til selvforsvar. Lad os så også holde fast i en anden ting: Hamas og Hizbollah vil ikke acceptere Israels eksistens. Og hver gang - det er så den tredje ting, hr. Rune Lund burde være opmærksom på - man nærmer sig en forståelse mellem regeringerne i Libanon, i Israel og den palæstinensiske regering, slår Hamas og Hizbollah til. Det var, hvad der skete i sommer, og det udløste så sommerens krig, som betød, at Israel overdrev sit selvforsvar. Det har vi også påtalt.

Fx EU har jo mulighed for gennem præcis disse aftaler at holde Israels forpligtelser op for landet og tage det op på møder, som man har med Israel. Det havde man så sent som den 9. november. Der blev holdt et møde i EU med Israel i komiteen for politisk dialog og samarbejde, hvor bl.a. det pågældende is- 
raelske angreb i Beit Hanun blev taget op fra EU's side. Havde vi ikke haft den aftale, havde vi ikke haft platformen til det. Også i juni måned var associeringsaftalen rammen om både et møde i Associeringsrå$\operatorname{det} \mathrm{EU} /$ Israel samt et møde i arbejdsgruppen for menneskerettigheder. I alle disse sammenhænge benyttes associeringsaftalen altså aktivt af EU til at drøfte disse spørgsmål. Uden aftalen havde vi ikke haft disse muligheder og denne platform til at sige til Israel klart og tydeligt, når de går over gevind.

\section{Rune Lund:}

Jeg startede med at sige, at Enhedslisten selvfølgelig anerkender Israels ret til at eksistere, Israels ret til selvforsvar, og det bygger selvfølgelig på, at vi i Enhedslisten ligesom så mange andre mener, at der bør findes en fredelig løsning på konflikten ud fra en tostatsløsning, sådan som det også er vedtaget i FN's Sikkerhedsråd.

Derfor fordømmer vi selvfølgelig også, hver eneste gang der bliver sendt raketter af sted, uanset om det er fra Gazastriben, eller det er fra Hizbollah, fordi det går ud over uskyldige israelske civile. Det skal stå helt fast.

Men det, som udenrigsministeren siger, lyder jo nærmest, som om dialog ikke er mulig, medmindre man har en handelsaftale. Selvfølgelig er dialog da mulig, selv om man fratager Israel de muligheder, de har for handel med EU som følge af den handelsaftale, der ligger.
Jeg må derfor spørge: Hvornår får denne dialog en konsekvens? Hvor mange civile palæstinensere skal dø, før man siger, at Israel ikke overholder menneskerettighederne, og før man siger, at vi nu bliver nødt til at opsige den her handelsaftale, fordi Israel simpelt hen ikke lever op til de helt grundlæggende forpligtelser i den aftale om at overholde menneskerettighederne?

\section{Udenrigsministeren:}

Ja, det kalder på to bemærkninger. Jeg håber, jeg kan nå dem begge.

Det første, hr. Rune Lund sagde, er jeg meget glad for, for der dementerede hr. Rune Lund jo pludselig sin kritik af min stemmeafgivning i Sikkerhedsrådet og generalforsamlingen. Hr. Rune Lund sagde: Der bør findes en tostatsløsning, således som Sikkerhedsrådet har vedtaget. Ja, Sikkerhedsrådet har vedtaget det ved at henvise til road map'en køreplanen for fred - og det vil sige, at havde vi ikke haft en sikkerhedsrådsbeslutning om køreplanen for fred, så havde vi ikke haft arbejdet for en tostatsløsning.

Så jeg er da glad for, at hr. Rune Lund nu virkelig er glad for, at jeg sikrede, at køreplanen for fred er med i generalforsamlingsteksten. Tak for den støtte, hr. Rune Lund!

Jeg er bare ikke helt sikker på, at hr. Rune Lund var klar over, han kom til at støtte mig.

Det andet er: Jamen hvis vi nu siger, at vi ikke vil have den handelsaf- 
tale, fordi Israel har økonomisk glæde af den, så er vi jo af hensyn til balancen nødt til at sige, at vi så i øvrigt også må holde op med at støtte palæstinenserne økonomisk, for vi skal jo gå efter en tostatsløsning og behandle begge parter ens. Der kommer jo raketter ind i Israel hele tiden.

Så hr. Rune Lunds forslag er altså at ophæve handelsaftalen og lade være med at støtte palæstinenserne. Det er bare ikke min politik.

\section{Rune Lund:}

Næ, min politik er: Ophæv handelsaftalen, når Israel ikke lever op til forpligtelserne om at overholde menneskerettighederne. Jeg synes, det er et meget godt princip, at hvis der er nogle regler i en aftale, så skal man leve op til reglerne i den aftale, og hvis reglerne ikke bliver overholdt, så må man tage konsekvensen og indgå i en dialog. Når man har taget den dialog hundrede sytten gange, og der stadig væk bliver myrdet civile palæstinensere hver eneste dag, så må man på et tidspunkt også tage konsekvensen af, at dialogen ikke fører nogen vegne, og så må man opsige handelsaftalen. Det er det, der er mit argument. Mit argument går selvfølgelig også ud på at støtte palæstinenserne.

Med hensyn til udenrigsministerens bortforklaringer i forbindelse med den der resolution, som man undlod at stemme for, så fik vi diskuteret det rigeligt under sidste punkt, så det vil jeg lade være ved det.
Men jeg vil gerne lige spørge udenrigsministeren: Når nu udenrigsministeren mener, at man skal indgå i en kritisk dialog med Israel, men har en meget hård og meget håndfast tilgang til fx det palæstinensiske selvstyre, fordi Hamas vandt et valg, hvordan har udenrigsministeren det så med, at Ehud Olmert har lavet en ny ministerrokade, hvor Liebermann er blevet minister, en minister, som kommer fra et ultra højreorienteret nationalistisk parti, som bl.a. arbejder for et racerent Israel?

Hvad er lige præcis forskellen på sådan en som Liebermann og de mest fundamentalistiske kræfter inden for Hamas? Det kunne jeg godt tænke mig udenrigsministerens svar på.

\section{Udenrigsministeren:}

Der er en meget væsentlig forskel. Hr. Liebermann styrer ikke Israels regering. Jeg har ikke set et eneste træk, hvor Olmert har imødekommet de ting, som hr. Rune Lund siger, og som er dybt kritisable i hr. Liebermanns holdninger.

Men det er altså sådan, at Hamas i Damaskus styrer Hamas i Gaza og styrede dem ind i den fuldstændig vanvittige krig i sommer. Så det vil sige, at vi altså her er udsat for en ubetydelig minister, som ikke styrer Israels regering, samtidig med at der på den anden side sidder en terrorbevægelse, som ikke accepterer Israels eksistens. Israel accepterer faktisk Palæstinas eksistens, de går ind 
for tostatsløsningen, og det gør Abbas også, og derfor støtter vi Abbas. Men det gør Hamas ikke...

\section{Naser Khader (R):}

Det er jo det, vi er gode venner med Israel, og derfor skal vi benytte os af disse gode relationer til at fortælle dem, hvad vi mener uden omsvøb. Har de fået at vide, at hvis de bliver ved med en overdreven gengældelsesstrategi, så kan der komme et tidspunkt, hvor vi er nødt til at bruge sanktioner? Er det blevet fortalt?

\section{Udenrigsministeren:}

Det er ikke blevet fortalt, for det er ikke regeringens politik at komme med sanktioner. Jeg tror faktisk ikke, at sanktioner er noget som helst værd. Det har jeg også sagt i Nævnet flere gange. Israels økonomi er ikke afhængig af turisme fra Europa, så hvis Israel alene skulle tage hensyn til pengepungen, ville der have været ført en anden politik.

Israel er i en eksistenskamp, og derfor tror jeg ikke, at sanktioner overhovedet ville hjælpe. Det er en dialog, en forståelse for deres ret til selvforsvar, en forståelse for, at de lever med to bevægelser, der prøver at udslette dem, og som rigtigt nok har fået større indflydelse. Jeg tror, hr. Khader er enig med mig i, at Israels måde at agere på også har givet dem større tilslutning i Libanon og i Gaza.

Så vi advarer mod den politik, de har, men sanktioner tror jeg ikke har nogen som helst virkning, og derfor har jeg heller ikke truet med dem. Man skal ikke true med noget, man ikke vil lave.

\section{Rune Lund:}

Nu er det jo sådan, at det jo ikke er helt fremmed for EU at opsige handelsaftaler med andre lande, hvis der foregår overgreb mod menneskerettighederne. Vi har jo med hensyn til Usbekistan set, at EU har opsagt en handelsaftale, fordi Usbekistan ikke kan overholde menneskerettighederne, fordi der foregår overgreb mod menneskerettighederne.

Så mit sidste og afsluttende spørgsmål til udenrigsministeren er: Hvad er det lige præcis, forskellen på Usbekistan og Israel er ud over den, at overgrebene i Israel mod menneskerettighederne er meget værre, end de er i Usbekistan?

\section{Udenrigsminister Per Stig Møller:}

Det kan jeg sige ganske kort. Der er ikke nogen, der prøver at udslette Usbekistan, men der er altså, som jeg har sagt flere gange i dag, to meget stærke militante bevægelser uden for regeringskontrol, som truer Israels eksistens og i sommer udløste en krig. Og med Usbekistan har vi jo præcis også haft held med vores politik, idet vi nu altså har fået gennemtrumfet, at der skal gøres en stærkere indsats for menneskerettighederne i Usbekistan. Så også der har vores politik altså virket.

Folketinget, 22. november 2006 